\title{
Glutamate-induced obesity leads to decreased sperm reserves and acceleration of transit time in the epididymis of adult male rats
}

\author{
Glaura SA Fernandes ${ }^{1}$, Arielle C Arena ${ }^{2 *}$, Kleber E Campos ${ }^{3}$, Gustavo T Volpato ${ }^{3}$, Janete A Anselmo-Franci ${ }^{4}$, \\ Débora C Damasceno ${ }^{5}$ and Wilma G Kempinas $^{2}$
}

\begin{abstract}
Background: Given the established fact that obesity interferes with male reproductive functions, the present study aimed to evaluate sperm production in the testis and storage in the epididymis in a glutamate-induced model of obesity.

Methods: Male rats were treated neonatally with monosodium glutamate (MSG) at doses of $4 \mathrm{mg} / \mathrm{kg}$ subcutaneously, or with saline solution (control group), on postnatal days 2, 4, 6, 8 and 10. On day 120, obesity was confirmed by the Lee index in all MSG-treated rats. After this, all animals from the two experimental groups were anesthetized and killed to evaluate body and reproductive organ weights, sperm parameters, plasma hormone levels (FSH, LH and testosterone), testicular and epididymal histo-morphometry and histopathology.

Results: Significant reductions in absolute and relative weights of testis, epididymis, prostate and seminal vesicle were noted in MSG-treated animals. In these same animals plasma testosterone and follicle-stimulating hormone (FSH) concentrations were decreased, as well as sperm counts in the testis and epididymis and seminiferous epithelium height and tubular diameter. The sperm transit time was accelerated in obese rats. However, the number of Sertoli cells per seminiferous tubule and stereological findings on the epididymis were not markedly changed by obesity.

Conclusions: Neonatal MSG-administered model of obesity lowers sperm production and leads to a reduction in sperm storage in the epididymis of adult male rats. The acceleration of sperm transit time can have implications for the sperm quality of these rats.
\end{abstract}

Keywords: Obesity, Monosodium glutamate, Epididymis, Testosterone, Sperm, Rat

\section{Background}

Obesity is increasing worldwide and it represents a challenge to the scientific community being major public health concern [1]. It is a heterogeneous disorder with wide variations in risks for complicating diseases [2] and has been associated with an increased risk of many serious illnesses such as cardiovascular diseases, diabetes mellitus and some types of cancer [3].

Although the negative effects of obesity on reproductive function were first documented more than 2000

\footnotetext{
* Correspondence: ariellearena@ibb.unesp.br

${ }^{2}$ Department of Morphology, Institute of Biosciences, UNESP -

UnivEstadualPaulista, Botucatu, SP, Brazil

Full list of author information is available at the end of the article
}

years ago by Hippocrates [4], the etiology of the adverse effects of this relationship has not been studied in depth. There is little data on human male reproductive outcomes, but have shown that overweight and obese men present hormonal changes such as lower plasma levels of sex hormone-binding globulin (SHBG), total testosterone, free testosterone and follicle-stimulating hormone (FSH) [5-7]. Nevertheless, lower sperm counts [8,9], poor semen quality [7], decreased normal-motile sperm cells and increased DNA fragmentation index [10] were described in men that showed increased body mass index (BMI). Recent information obtained from different population studies suggests an inverse relationship between the increase in body mass index and fertility

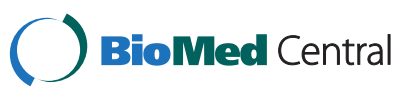


$[7,11]$. However, there were few studies that relate obesity to male reproductive dysfunction, and the existents are inconclusive. According to Sallmen et al. [9], programs to prevent obesity may improve men's reproductive health and save medical costs for infertility treatment.

Due to the difficulty of studying obesity-induced reproductive complications in men, experimental models have been used. The induction of obesity may be performed in animals by neuroendocrine, dietary or genetic changes [12]. According to one of these models if neonatal rats are treated with monosodium glutamate (MSG) in the neonatal period, they become obese through the course of development [13-19]. Neonatal MSG treatment leads to the destruction of specific sites in the hypothalamus, including ventromedial and arcuate nuclei, in turn provoking disorders in the control of absorption and energy-expenditure-specific mechanisms resulting in a state of obesity $[20,21]$.

No study evaluated the effects of this obesity model on the epididymal structure or function -organ responsible for sperm maturation and survival [22]. Thus, the present study aimed to evaluate the histopathology, morphometry and storage sperm in the epididymis in obese male rats due to neonatal MSG treatment. Nevertheless, plasma hormonal assay, sperm production and morphometric analysis in the testis were also evaluated.

\section{Methods}

\section{Parental generation}

Wistar rats (males, $\mathrm{n}=4$ and females, $\mathrm{n}=10$ ) weighing about $180 \mathrm{~g}$ (90 days of life), were adapted for seven days in the Laboratory of Experimental Research of Gynecology and Obstetrics, Department of Gynecology and Obstetrics. The rats were kept in collective cages in controlled conditions of temperature $\left(22 \pm 3^{\circ} \mathrm{C}\right)$, light (12h light/dark cycle) and relative humidity $(60 \pm 5 \%)$. The animals were fed laboratory chow (Purina ${ }^{\circledR}$ ) and tap water ad libitum. All experimental procedures carried out in this study were approved by the Committee for Ethics in Animal Experimentation at the School of Medicine of Botucatu - Unesp, São Paulo State, Brazil (Protocol number: 318/2003).

Females $(n=10)$ were mated overnight with normal males and sperm presence in vaginal wet smears in the following morning was defined as day zero (0) of pregnancy. Pregnant rats were kept in individual cages during the pregnancy period (21 days), including vaginal delivery and lactation periods (21 days).

\section{Experimental rats}

From the offspring obtained, eight newborns (NB) were kept with their dams (one newborn/nipple, preferentially males) throughout the lactation period (21 days). When the number of males would not reach eight, female NBs were placed in the litter. This procedure was utilized to obtain better and equal feeding for all NBs.

Male offspring were divided into two groups: rats that received saline solution $(2.0 \% \mathrm{NaCl}-$ Control) subcutaneously (sc) at postnatal days 2, 4, 6, 8 and 10 (Control group, $n=9)$ and rats given a solution of monosodium glutamate (MSG - $4.0 \mathrm{mg} / \mathrm{g}$ body weight, sc) at same days as those of the control group (MSG group, $n=9$ ) [15,19,23-25]. After weaning, male rats were transferred to collective cages (4 animals per cage) and kept in controlled conditions. This methodology is related to induce lipohypertrophyin periepididymal fat [15].

\section{Obesity parameter of male rats}

The parameter of obesity was obtained by Lee index for each male rat at month 4 of life (120 days). This index was defined as the cube root of body weight (g) x 10 / nasoanal length $(\mathrm{cm})$, for which a value equal to or less than 0.300 was classified as normal. Rats presenting values higher than 0.300 were classified as obese $[24,26]$ and included in this experiment.

\section{Body weight and weight of male reproductive organs}

In adult age (120 days old), male rats from two experimental groups ( $\mathrm{n}=9$; 1 per litter) were weighed and killed by decapitation. The left testis and epididymis, vas deferens, ventral prostate and seminal vesicle (without the coagulating gland and full of secretion) were removed and their absolute and relative weights determined.

\section{Plasma hormonal assay}

After decapitation of each rat, blood (between 0900 and $1100 \mathrm{~h} \mathrm{am}$ ) from the ruptured cervical vessel was collected in a heparinized tube and evaluated for the determination of plasma testosterone ( $\mathrm{T}$ ), follicle-stimulating hormone (FSH) and luteinizing hormone (LH) levels. The plasma was obtained after centrifugation $\left(2400 \mathrm{rpm}, 20 \mathrm{~min}, 3.5^{\circ} \mathrm{C}\right)$ in a refrigerated apparatus and was frozen at $-20^{\circ} \mathrm{C}$ until the moment of hormonal determination. Plasma hormone levels were determined by double-antibody radioimmunoassay, using the Testosterone Maia ${ }^{\circledR}$ kit (BiochemImmuno System) and specific kits for FSH and LH, at the Neroendocrinology Laboratory, Dental School of Ribeirão Preto, University of São Paulo - USP. All the samples were dosed in the same assay, to avoid inter-assay errors. The lower detection limit was $0.064 \mathrm{ng} / \mathrm{mL}$, with a $4 \%$ intra-assay error for $\mathrm{T}$; $0.04 \mathrm{ng} / \mathrm{mL}$, with a $3.4 \%$ intra-assay error for $\mathrm{LH}$; and $0.09 \mathrm{ng} / \mathrm{mL}$, with a $2.8 \%$ intra-assay error for FSH.

\section{Daily sperm production per testis, sperm number and transit time in the epididymis}

Homogenization-resistant testicular spermatids (step 19 of spermiogenesis) and sperm in the caput/corpus 
epididymis and cauda epididymis were enumerated as described previously by Robb et al. [27], with adaptations adopted by Fernandes et al. [28]. Briefly, each left testis, decapsulated and weighed soon after collection, was homogenized in $5 \mathrm{ml}$ of $\mathrm{NaCl} 0.9 \%$ containing Triton $\mathrm{X}$ $1000.5 \%$, followed by sonication for $30 \mathrm{sec}$. After a 10fold dilution a sample was transferred to Newbauer chambers (4 fields per animal), preceding a count of mature spermatids. To calculate daily sperm production (DSP) the number of spermatids at step 19 was divided by 6.1 , which is the number of days of the seminiferous cycle in which these spermatids are present in the seminiferous epithelium. Then, the DSP per gram was calculated in order to determine the efficiency of the process [29]. In the same manner, caput/corpus and cauda epididymidis portions were cut into small fragments with scissors and homogenized, and sperm counted as described for the testis. The sperm transit time through the epididymis was determined by dividing the number of sperm in each portion by the DSP.

\section{Histopathological evaluation}

The right testis and epididymis in 5 animals per group were removed and fixed in Alfac fixing solution (80\% ethanol, formaldehyde and glacial acetic acid, 8.5:1.0:0.5, $\mathrm{v} / \mathrm{v}$ ) for $24 \mathrm{~h}$. The pieces were embedded in paraffin wax and sectioned at $7 \mu \mathrm{m}$. The sections were stained with hematoxylin and eosin ( $\mathrm{H} \& \mathrm{E})$.

\section{Morphometric and stereological analysis}

Using an imaging analysis system (Leica Q-Win Software version 3 for Windows ${ }^{\mathrm{TM}}$ ), the testicular morphometry and stereological analyses of the epididymis (cauda, region 6A) were accomplished by utilizing $\mathrm{H} \& \mathrm{E}$ sections [28]. Morphometric analysis was performed to evaluate seminiferous epithelium height and tubular diameter. For this study 10 sections per animal were measured (stage IX of spermatogenic cycle) at X 200 magnification.

Random H\&E images of 75 histological fields per experimental group were captured and analyzed by the stereological method such that histological fragments of all animals were evaluated equally (15 per animal). Stereological analyses were obtained by Weibel's multipurpose graticulate, with 120 points and 60 test lines [30] to compare the epididymal components (epithelium, stroma and lumen) in the experimental groups.

\section{Number of Sertoli cells per seminiferous tubule}

To evaluate the process of proliferation of Sertoli cells, nuclei were counted in histological cuts (5- $\mu \mathrm{m}$-thick) from the testis of rats at adulthood, in 20 seminiferous tubules per rat at stage VII of spermatogenesis, classified according to Leblond and Clermont [31].

\section{Statistical analysis}

For comparison of results between the experimental groups, the Student's $t$-test or Mann-Whitney test was employed according to the characteristics of each variable. The results were considered significant for $p<0.05$.

\section{Results}

Table 1 shows the Lee index range found in both groups. Although there was data for obesity in control group in some rats, obesity was totally confirmed by Lee index in all rats of MSG - treated group (Table 1) which showed significant diminished body weight and naso-anal length in relation to control group. Nevertheless, male obese rats presented significant reductions in absolute and relative weights of the testis, epididymis, prostate and seminal vesicle (Table 1). Plasma testosterone and FSH levels were significantly diminished in male obese rats. However, plasma LH levels presented similarity between groups (Table 2).

Experimental obesity led to a significant decrease in the numbers of testicular spermatids and sperm in the caput/corpus and cauda epididymidis, and a significant decrease in daily sperm production (DSP) (Table 3). However, there was no significant decrease in DSP/g of testis in the MSG group. In the male obese rats there was also a significant reduction in the sperm transit time in the cauda epididymidis, but not in the caput/corpus epididymidis (Table 3 ).

Histopathological evaluation of the testis and epididymis did not reveal treatment-related morphological alterations (data not shown). The morphometric testicular analysis showed significant reductions in tubular diameter and seminiferous epithelium height in male obese rats (Table 4). The Sertoli cell number per seminiferous tubule (Control: $18.46 \pm 1.57$ and MSG: $16.02 \pm 1.83$;

\begin{tabular}{|c|c|c|}
\hline Groups & Control $(n=9)$ & MSG $(n=9)$ \\
\hline Lee index range & $0.189-0.314$ & $0.369-0.424$ \\
\hline Final body weight (g) & $487.30 \pm 12.10$ & $421.40 \pm 10.72^{*}$ \\
\hline Naso-anal length (cm) & $24.10 \pm 0.25$ & $18.50 \pm 0.50^{*}$ \\
\hline Testis (g) & $1.66 \pm 0.08$ & $1.00 \pm 0.06^{*}$ \\
\hline Testis $(\mathrm{g} / 100 \mathrm{~g})$ & $0.34 \pm 0.02$ & $0.24 \pm 0.01^{*}$ \\
\hline Epididymis (mg) & $668.83 \pm 20.00$ & $392.00 \pm 32.24^{*}$ \\
\hline Epididymis (mg/100g) & $138.42 \pm 5.17$ & $93.00 \pm 6.60^{*}$ \\
\hline Ventral prostate (mg) & $605.50 \pm 38.74$ & $220.00 \pm 68.70^{*}$ \\
\hline Ventral prostate $(\mathrm{mg} / 100 \mathrm{~g})$ & $125.11 \pm 9.00$ & $50.96 \pm 15.70^{*}$ \\
\hline Seminal vesicle (g) & $1.70 \pm 0.18$ & $0.44 \pm 0.10^{*}$ \\
\hline Seminal vesicle $(g / 100 g)$ & $0.35 \pm 0.03$ & $0.10 \pm 0.02^{*}$ \\
\hline
\end{tabular}

Values are expressed as mean \pm SEM. ${ }^{*} p<0.05$ (Student's $t$-test). 
Table 2 Plasma hormonal levels from control and MSG groups

\begin{tabular}{lcc}
\hline Groups & Control $(\mathbf{n}=\mathbf{9})$ & MSG $(\mathbf{n}=\mathbf{9})$ \\
\hline FSH $(\mathrm{ng} / \mathrm{mL})$ & $7.05 \pm 0.79$ & $4.86 \pm 0.64^{*}$ \\
$\mathrm{LH}(\mathrm{ng} / \mathrm{mL})$ & $3.05 \pm 0.87$ & $3.83 \pm 0.90$ \\
Testosterone $(\mathrm{ng} / \mathrm{mL})$ & $1.52 \pm 0.19$ & $0.57 \pm 0.06^{*}$ \\
\hline
\end{tabular}

Values are expressed as mean \pm SEM. ${ }^{*} p<0.05$ (Student's $t$-test).

$\mathrm{p}>0.05$ - mean \pm S.E.M.) and the epididymal stereological analysis showed similarity between the groups (Table 4).

\section{Discussion}

Our study demonstrates that neonatal treatment with MSG alters the epididymal parameters by reducing sperm storage and accelerating sperm transit time. Furthermore, the present data confirm previous results showing that neonatal treatment with MSG is able to induce obesity (high Lee index, small corporal weight and naso-anal length) [32-36] although few control rats also presented obesity status by Lee index, related to aging [19]. Thus, neonatal treatment with MSG caused a cessation of growth and development with a concomitant accumulation of body fat leading to a decrease in body weight in relation to control group. Neonatal MSG treatment is a model of obesity in rodents which causes alterations in hypothalamic arcuate nucleus (ARC) and impairs leptin and insulin signaling in this region [37-39] resulting in hyperleptinemia and hyperinsulinemia. When the hypothalamic ventromedial nucleus and arcuate nucleus are destroyed in rats by treatment with MSG in the neonatal stage, obesity occurs as the rats grow [40].

Wet-weight alterations in the reproductive organs constitute a parameter for indicating changes in sex hormone levels [41]. In this study, the significant reduction in the weights of all analyzed organs in obese rats corroborate with the reduction of testosterone levels. As mentioned previously, the obesity induced by glutamate is obtained
Table 4 Morphometric and stereological analyses from control and MSG groups

\begin{tabular}{lcc}
\hline Groups & Control $(\mathbf{n}=\mathbf{5})$ & MSG $(\mathbf{n}=\mathbf{5})$ \\
\hline $\begin{array}{c}\text { Testicular morphometry } \\
\text { Tubular diameter }\end{array}$ & $289.82 \pm 4.14$ & $269.61 \pm 3.72^{*}$ \\
Epithelium height & $80.02 \pm 1.40$ & $75.86 \pm 1.40^{*}$ \\
${ }^{\mathbf{1} E p \text { ididymal stereology }}$ & & \\
Epithelium & $5.95[4.76-7.74]$ & $6.55[4.76-7.74]$ \\
Stroma & $25.60[16.81-26.04]$ & $21.43[19.05-31.70]$ \\
Lumen & $68.45[67.26-77.38]$ & $70.83[62.36-75.60]$
\end{tabular}

Values are expressed as mean \pm SEM. ${ }^{*} p<0.05$ (Student's $t$-test).

${ }^{1}$ Values are expressed as median followed by quartile intervals [Q1-Q3].

$p>0.05$ (Mann Whitney test).

through a hypothalamic injury that disrupts the secretion of hormones including the gonadotrophins (FSH and $\mathrm{LH}$ ) [42,43]. According to França et al. [18], in this obesity model, significant diminutions in the testosterone and FSH levels are related to disrupted HPG axis development due to the hyperleptinemia. In the same manner, Tena-Sempere et al. [44] reported that a possible cause for this severe reduction in the testosterone levels in animals neonatally treated with glutamate may have been due to an increase in plasma leptin levels. However, despite the decreased testosterone and FSH levels, the LH levels (hormone directly involved in regulating testosterone secretion) were unchanged by MSG treatment. This result can be related with severe ARC lesions [24,45,46] and so we suggest that MSG specifically leads to lesions in FSH neurons. Moreover, it is important to emphasize that the hormonal profile of obese men is characterized by decreased total and, often, free testosterone levels, diminished gonadotropin levels, and increased circulating estrogen levels [47].

The number of spermatids present in the testis and the total DSP are important indicators of male fertility potential [29]. In the present study, the reduction in sperm

Table 3 Epididymal and testicular sperm parameters from control and MSG groups

\begin{tabular}{|c|c|c|}
\hline Groups & Control $(n=9)$ & MSG $(n=9)$ \\
\hline Daily sperm production ( $\times 10^{6} /$ testis/day) & $43.13 \pm 1.62$ & $21.90 \pm 1.24^{*}$ \\
\hline Daily sperm production ( $\times 10^{6} / \mathrm{g}$ of testis/day) & $27.30 \pm 0.81$ & $26.87 \pm 1.81$ \\
\hline Sperm count in the testis ( $\times 10^{6}$ /organ) & $263.00 \pm 10.00$ & $134.70 \pm 8.00^{*}$ \\
\hline Relative sperm count in the testis ( $\times 10^{6} / \mathrm{g}$ of organ) & $166.50 \pm 5.00$ & $163.83 \pm 11.10$ \\
\hline Sperm count in the caput/corpus epididymis (x $10^{6}$ /organ) & $172.15 \pm 5.60$ & $76.43 \pm 5.60^{*}$ \\
\hline Relative sperm count in the caput/corpus epididymis (x $10^{6} / \mathrm{g}$ of organ) & $516.01 \pm 20.24$ & $382.56 \pm 18.00^{*}$ \\
\hline Sperm count in the cauda epididymis $\left(\times 10^{6} / \mathrm{g}\right)$ & $335.16 \pm 11.85$ & $126.13 \pm 22.12^{*}$ \\
\hline Relative sperm count in the cauda epididymis ( $\times 10^{6} / \mathrm{g}$ of organ) & $1122.00 \pm 27.27$ & $861.16 \pm 42.34^{*}$ \\
\hline Sperm transit time in the caput/corpus (days) & $4.00 \pm 0.09$ & $3.51 \pm 0.23$ \\
\hline Sperm transit time in the cauda (days) & $7.90 \pm 0.46$ & $5.70 \pm 0.84^{*}$ \\
\hline
\end{tabular}

Values are expressed as mean \pm SEM. ${ }^{*} p<0.05$ (Student's $t$-test). 
production led by MSG-induced obesity was associated with reduced testicular weight, seminiferous tubular diameter, testicular seminiferous epithelium height and testosterone and FSH levels. On the other hand, França et al. [18] showed unchanged sperm production, testis weight and seminiferous tubular diameter in obese adult rats after neonatal glutamate-induced obesity. In this sense, it is known that the number of Sertoli cells, established during the prepubertal period, determines the final testicular size and the magnitude of sperm production in sexually mature animals [48-50]. In the present study the number of Sertoli cells did not change in the obese rats, as well as the efficiency of the spermatogenic process, as evidenced by results of DSP per gram of testis that were similar between the experimental groups. It is possible that the disturbance in the HPG axis due to MSG treatment compromises the real significance of reduced FSH plasma levels observed in the present model. Evaluation of inhibin B levels in MSG rats could provide additional information regarding Sertoli cell function [18]. Thus, this experimental model may produces lightly different results between different research groups, as disclosed in the literature.

The reduction in sperm count in the epididymis in obese rats was probably responsible by the decrease of the epididymal weight and contributed for the acceleration of the sperm transit time through the epididymis. Acceleration in sperm transit time can impair sperm maturation and reduce the number of gametes available for ejaculation and fertility [51]. These alteration were independent of epididymal components (epithelium, stroma and lumen) since they are unaffected by glutamate-induced obesity.

It is very known that in obesity conditions there is an excess of leptin which is secreted by the adipocytes [44]. Studies show that the plasma leptin concentrations were significantly elevated in both humans $[52,53]$ and in rodent obesity models $[54,55]$, and directly proportional to the amount of fat. Leptin is important for the regulation of food intake, energy metabolism and reproductive function [55-58]. It has been proposed that a specific narrow leptin concentration range is necessary to maintain normal reproductive function, and levels below or above these thresholds are critical to this peptide's influence on the function of the hypothalamus-pituitary-gonadal (HPG) axis $[57,58]$ by acting on hypothalamic receptors and also by promoting peripheral effects [17]. However, the relationship between high leptin levels and the male reproductive system is not clear.

\section{Conclusions}

In conclusion, the neonatal MSG-administered model of obesity lowers sperm production and leads to a reduction in sperm storage in adult male rats. Moreover, the acceleration of sperm transit time can have implications for the sperm quality of these rats. Thus, further studies should address (sperm motility, DNA integrity and fertility assay) the relationship between glutamate-induced obesity and epididymis function.

\section{Competing interests}

The authors declare that they have no competing interests.

\section{Authors' contributions}

All authors participated in the design, interpretation of the studies, analysis of the data and review of the manuscript; GSAF and ACA conducted the experiments; KEC, GTV and DCD induced the obesity; JAAF performed hormone assay; and GSAF, ACA and WDGK performed data analyses and wrote the manuscript. All authors read and approved the final manuscript.

\section{Acknowledgements}

The authors are thankful to Mr. Benedito Cláudio da Silva and Mr. José Eduardo Bozano for technical assistance. Financial support came from the National Council for Scientific and Technological Development (CNPq).

\section{Author details}

${ }^{1}$ Biological Sciences Center, State University of Londrina, UEL, Londrina, PR, Brazil. ${ }^{2}$ Department of Morphology, Institute of Biosciences, UNESP UnivEstadualPaulista, Botucatu, SP, Brazil. ${ }^{3}$ Institute of Biological and Health Sciences, Federal University of Mato Grosso, UFMT, Barra do Garça, MT, Brazil. ${ }^{4}$ Department of Physiology, Ribeirão Preto Medical School, University of São Paulo, USP, Ribeirão Preto, SP, Brazil. ${ }^{5}$ Laboratory of Experimental Research on Gynecology and Obstetrics, Department of Gynecology and Obstetrics, Botucatu Medical School, UNESP - UnivEstadualPaulista, Botucatu, SP, Brazil.

Received: 30 August 2012 Accepted: 29 November 2012

Published: 5 December 2012

\section{References}

1. WHO - World Health Organization: World Health Organization. Obesity: preventing and managing the global epidemic. 894. Geneva: WHO Technical Report Series; 2000. Part l: The problem of overweight and obesity.

2. Pasquali R: Obesity, fat distribution and infertility. Maturitas 2006 54(4):363-371.

3. Visscher TL, Seidell JC: The public health impact of obesity. Annu Rev Public Health 2001, 22(1):355-375.

4. Bray GA: Obesity: historical development of scientific and cultural ideas. Int J Obes 1990, 14(11):909-926.

5. Strain GW, Zumoff B, Kream J, Strain JJ, Deucher R, Rosenfeld RS, Levin J, Fukushima DK: Mild hypogonadotropichypogonadism in obese men. Metabolism 1982, 31(9):871-875.

6. Haffner SM, Valdez RA, Stern MP, Katz MS: Obesity, body fat distribution and sex hormones in men. Int J Obes Relat Metab Disord 1993, 17(11):643-649.

7. Magnusdottir EV, Thorsteinsson T, Thorsteinsdottir S, Heimisdottir M, Olafsdottir K: Persistent organochlorines, sedentary occupation, obesity and human male subfertility. Human Reprod 2005, 20(1):208-215.

8. Jensen TK, Andersson AM, Jørgensen N, Andersen AG, Carlsen E, Petersen $\mathrm{JH}$, Skakkebæk NE: Body mass index in relation to semen quality and reproductive hormones among 1,558 Danish men. Fertil Steril 2004, 82(4):863-870

9. Sallmen M, Sandler DP, Hoppin JA, Blair A, Baird DD: Reduced fertility among overweight and obese men. Epidemiology 2006, 17(5):520-523.

10. Kort HI, Massey JB, Elsner CW, Mitchell-Leef D, Shapiro DB, Witt MA Roudebush WE: Impact of body mass index values on sperm quantity and quality. J Androl 2006, 27(3):450-452.

11. Vigueras-Villaseñor RM, Rojas-Castañeda JC, Chávez-Saldaña M, GutiérrezPérez O, García-Cruz EM, Cuevas-Alpuche O, Reyes-Romero MM, Zambrano $\mathrm{E}$ : Alterations in the spermatic function generated by obesity in rats. Acta Histochem 2011, 113(2):214-220.

12. York DA: Lessons from animal models of obesity. Endocrinol Metab Clin North Am 1996, 25(4):781-800.

13. Sukhanov SN, Andrade IS, Dolnikoff MS, Ferreira A: Neonatal monosodium glutamate treatment alters rat intestinal muscle reactivity to some agonists. Eur J Pharmacol 1999, 386(2-3):247-252.

14. Mello MAR, Souza T, Braga LR, Santos W, Ribeiro IA, Gobatto CA: Glucose tolerance and insulin action in monosodium glutamate (MSG) obese exercise-trained rats. Physio/ Chem Phys Med NMR 2001, 33(1):63-71. 
15. Cunha NV, Abreu SB, Panisb C, Grassiollia S, Guarnierb FA, Cecchinib R, Mazzucob TL, Pinge-Filho P, Martins-Pinge MC: Cox-2 inhibition attenuates cardiovascular and inflammatory aspects in monosodium glutamateinduced obese rats. Life Sci 2010, 87:375-381.

16. Lyon HN, Hirschhorn JN: Genetics of common forms of obesity: a brief overview. Am J Clin Nutr 2005, 82(1):215S-217S.

17. Bueno AA, Oyama LM, Estadella D, Habitante CA, Bernardes BSS, Ribeiro EB, Oller CMN: Lipid metabolism of monosodium glutamate obese rats after partial removal of adipose tissue. Physiol Res 2005, 54(1):57-65.

18. França LR, Suescum MO, Miranda JR, Giovambattista A, Perello M, Spinedi E, Calandra RS: Testis structure and function in a nongenetichyperadipose rat model at prepubertal and adult ages. Endocrinology 2006, 147(3):1556-1563.

19. Campos KE, Sinzato YK, Pimenta WP, Rudge MVC, Damasceno DC: Effect of maternal obesity on diabetes development in adult rat offspring. Life Sci 2007, 81(19-20):1473-1478

20. Dolnikoff M, Martin-Hidalgo A, Machado UF, Lima FB, Herrera E: Decreased lipolysis and enhanced glycerol and glucose utilization by adipose tissue prior to development of obesity in monosodium glutamate (MSG) treated-rats. Int J Obes Relat Metab Disord 2001, 25(3):426-433.

21. Diemen $W$, Trindade EN, Trindade MRM: Experimental model to induce obesity in rats. Acta Cir Bras 2006, 21(6):425-429.

22. Hermo L, Robaire B: Epididymal cell types and their functions. In The Epididymis - From Molecules to Clinical Practice. Edited by Robaire B, Hinton BT. New York: Kluwer Academic / Plenum Publisher; 2002:81-102.

23. Otoya RE, Seltzer AM, Donoso AO: Decrease of (+)-3-[25]]MK-801 binding to NMDA brain receptors revealed at puberty in rats treated neonatally with monosodium glutamate. Brain Res Dev Brain Res 1996, 95(2):149-156.

24. Bernardis LL: Prediction of carcass fat, water, and lean body mass from Lee's "Nutritive Ratio" in rats with hypothalamic obesity. Experientia 1970, 26:789-790.

25. Sanabria ER, Pereira MF, Dolninkoff MS, Andrade IS, Ferreira AT, Cavalheiro EA: Deficit in hippocampal long-term potentiation in monosodium glutamate-treated rats. Brain Res Bull 2002, 59(1):47-51.

26. Bernardis LL, Patterson BD: Correlation between "Lee index" and carcass fat content in weanling and adult female rats with hypothalamic lesions. J Endocrinol 1968, 40(4):527-528.

27. Robb GW, Amann RP, Killian GJ: Daily sperm production and epididymal sperm reserves of pubertal and adult rats. J Reprod Fertil 1978, 54(1):103-107.

28. Fernandes GS, Arena AC, Fernandez CDB, Mercadante A, Barbisan LF, Kempinas WG: Reproductive effects in male rats exposed to diuron. ReprodToxicol 2007, 23(1):106-112

29. Ashby J, Tinwell H, Lefevre PA, Joiner R, Haseman J: The effect on sperm production in adult Sprague-Dawley rats exposed by gavage to bisphenol A between postnatal days 91-97. Toxicol Sci 2003, 74(1):129-138

30. Weibel ER: Principles and methods for the morphometric study of the lung and other organs. Lab Invest 1963, 12(1):131-155.

31. Leblond $\mathrm{CP}$, Clermont $\mathrm{Y}$ : Spermiogenesis of rat, mouse, hamster and guinea pig as revealed by the periodic acid-fuchsin sulfurous acid technique. Am J Anat 1952, 90(2):167-215.

32. Kanarek RB, Marks-Kaufman R: Increased carbohydrate consumption induced by neonatal administration of monosodium glutamate to rats. Neuro behav Toxicol Teratol 1981, 3(3):343-350.

33. Oida K, Nakai T, Hayashi T, Miyabo S, Takeda R: Plasma lipoproteins of monosodium glutamate-induced obese rats. Int J Obes 1984, 8(5):385-391.

34. Papa PC, Vargas AM, Silva JLT, Nunes MT, Machado UF: GLUT4 protein is differently modulated during development of obesity in monosodium glutamate-treated mice. Life Sci 2002, 71(16):1917-1928.

35. Mozeš S, Sefeikov Z, Lenhardt L, Racek L: Effect of adrenalectomy on the activity of small intestine enzymes in monosodium glutamate obese rats. Physiol Res 2004, 53(4):415-422.

36. Soares A, Schoffen JP, Gouveia EM, Natali MR: Effects of the neonatal treatment with monosodium glutamate on myenteric neurons and the intestine wall in the ileum of rats. J Gastroenterol 2006, 41(7):674-680.

37. Broberger $C$, Johansen J, Johansson C, Schalling M, Hökfelt T: The neuropeptide Y/agouti gene-related protein (AGRP) brain circuitry in normal, anorectic, and monosodium glutamate-treated mice. Proc Natl Acad Sci 1998, 95(25):15043-15048.

38. Dawson R, Pelleymounter MA, Millard WJ, Liu S, Eppler B: Attenuation of leptin-mediated effects by monosodium glutamate-induced arcuate nucleus damage. Am J Physiol 1997, 273(1 Pt 1):E202-E206
39. Maletínská L, Toma RS, Pirnik Z, Kiss A, Slaninová J, Haluzík M, Zelezná B: Effect of cholecystokinin on feeding is attenuated in monosodium glutamate obese mice. Regul Pept 2006, 136(1-3):58-63.

40. Nakagawa T, Ukai K, Ohyama T, Gomita Y, Okamura H: Effects of chronic administration of sibutramine on body weight, food intake and motor activity in neonatally monosodium glutamate-treated obese female rats: relationship of antiobesity effect with monoamines. Exp Anim 2000, 49:239-249

41. Zenick H, Clegg ED, Perreault SD, Klinefelter GR, Gray LE: Assessment of male reproductive toxicity: a risk assessment approach. In Principles and Methods of Toxicology. 3rd edition. Edited by Hayes AW. New York: Raven; 1994:937-988.

42. Dada MO, Blake CA: Administration of monosodium glutamate to neonatal male rats: alterations in the gonadotrophs and in gonadotrophin secretion. Neuroendocrinology 1984, 38(6):490-497.

43. Gong SL, Xia FQ, Wei J, Li XY, Sun TH, Lu Z, Liu SZ: Harmful effects of MSG on function of hypothalamus-pituitary-target gland system. Biomed Environ Sci 1995, 8(4):310-317.

44. Tena-Sempere M, Pinilla L, Gonzalez LC, Dieguez C, Casanueva FF, Aguilar E: Leptin inhibits testosterone secretion from adult rat testis in vitro. J Endocrinol 1999, 161(2):211-218.

45. Badger TM, Millard WJ, Martin JB, Rosenblum PM, Levenson SE: Hypothalamic-pituitary function in adult rats treated neonatally with monosodium glutamate. Endocrinology 1982, 111(6):2031-2038

46. Sridaran R, Rodriguez-Sierra JF, Blake CA: Effects of hypothalamic arcuate nucleus lesions on pulsatile luteinizing hormone concentration in ovariectomized rats. Proc Soc Exp Biol Med 1981, 168(1):38-44.

47. Hammoud AO, Gibson M, Peterson CM, Meikle AW, Carrell DT: Impact of male obesity on infertility: a critical review of the current literature. Fertil Steril 2008, 90(4):897-904

48. Orth JM: Cell biology of testicular development in fetus and neonate. In Cell and molecular biology of the testis. Edited by Desjardins C, Ewing LL. New York: Oxford University Press; 1993:3-42.

49. Berndtson WE, Igboeli G, Pickett BW: Relationship of absolute numbers of Sertoli cells to testicular size and spermatogenesis in young beef bulls. J AnimSci 1987, 64(1):241-246.

50. França LR, Russell LD: The testis of domestic animals. In Male reproduction: a multidisciplinary overview. Edited by Martínez-Garcia F, Regadera J. Madrid: Churchill Communications Europe España; 1998:197-219.

51. Kempinas WG, Klinefelter GR: The Epididymis as a Target for Toxicants. In Comprehensive Toxicology. Edited by Charlene A. McQueen: Oxford: Academic Press; 2010:149-166.

52. Maffei M, Halaas J, Ravussin E, Pratley RE, Lee GH, Zhang Y, Fei H, Kim S, Lallone R, Ranganathan S: Leptin levels in human and rodent: measurement of plasma leptin and ob RNA in obese and weight reduced subjects. Nat Med 1995, 1(11):1155-1161.

53. Considine RV, Sinha MK, Heinman ML, Kriavciunas A, Stephans TW, Nyce MR, Ohannesian JP, Marco CC, McKee L, Bauer TL, Caro JF: Serum immunoreactive-leptin concentrations in normal-weight and obese humans. N Engl J Med 1996, 334(5):292-295.

54. Fernandez CD, Bellentani FF, Fernandes GS, Perobelli JE, Favareto AP, Nascimento AF, Cicogna AC, Kempinas WD: Diet-induced obesity in rats leads to a decrease in sperm motility. Reprod Biol Endocrinol 2011, 11:9-32.

55. Magni P, Motta M, Martini L: Leptin: a possible link between food intake, energy expenditure, and reproductive function. Regul Pepti 2000, 92(1-3):51-56.

56. Barash IA, Cheung CC, Weigle DS, Ren H, Kabigting EB, Kuijper JL, Clifton DK, Steiner RA: Leptin is a metabolic signal to the reproductive system. Endocrinology 1996, 137(7):3144-3147.

57. Caprio M, Fabbrini E, Isidori AM, Aversa A, Fabbri A: Leptin in reproduction. Trends Endocrinol Metab 2001, 12(2):65-72.

58. Smith GD, Jackson LM, Foster DL: Leptin regulation of reproductive function and fertility. Theriogenology 2002, 57(1):73-86.

doi:10.1186/1477-7827-10-105

Cite this article as: Fernandes et al:: Glutamate-induced obesity leads to decreased sperm reserves and acceleration of transit time in the epididymis of adult male rats. Reproductive Biology and Endocrinology 2012 10:105 